\title{
APSA Ralph Bunche Summer Institute 3oth Anniversary: Celebrating 30 Years of Excellence
}

\author{
By Kimberly A. Mealy, Director of Diversity and Inclusion Programs
}

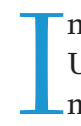
n 1986 political science professors Jewel L. Prestage (Southern University) and Peter Zwick (Louisiana State University) submitted a proposal, based on research conducted by the APSA Committee on the Status of Blacks, to the APSA Council for a joint summer program for African American students for the purpose of enhancing diversity within the discipline of political science. The original program was called the APSA Summer Institute for Blacks in Political Science. The program was approved and received four years of funding support from the Ford Foundation.

The first summer institute was held at Southern University in Baton Rouge, Louisiana, at a jointly sponsored program run by Southern University and Louisiana State University in summer of 1986 and continued there through 1989. Prestage and Zwick served as codirectors of the program. The National Conference of Black Political Scientists (NCOBPS) partnered with APSA to provide support with planning and student recruitment efforts, as well as outreach to potential faculty and advanced graduate students to speak at the program. Between 1988 and 1989 the program was renamed in honor of Ralph J. Bunche, 1950 Nobel Peace Prize winner, UN Undersecretary for Special Political Affairs and mediator, former APSA president (1953-1954), and the first African American to earn a $\mathrm{PhD}$ in political science.

Since then, the program has been held at various universitiesoften in partnerships. From 1990 to 1994, the RBSI program was held in Atlanta, Georgia, through a five-university consortium which included Spelman College, Clark-Atlanta University, Emory University, Georgia State University, and Morehouse College. Lois Morehead, of Spelman College, directed the program when it moved to Atlanta in 1990. In 1995, the RBSI program moved to the University of Virginia, and then to Duke University in 2000 (where it currently resides), in both instances under the direction of Paula McClain. The program's eligibility was expanded to include "all undergraduate students from underrepresented racial and ethnic groups or those interested in broadening participation in political science and pursuing scholarship on issues affecting underrepresented groups."

The RBSI Program has been host to students from nearly 30 colleges and universities around the country. Providing graduate-level coursework in research methodology and racial and ethnic politics, the RBSI faculty and curriculum helps to prepare attendees for graduate school. In the 30 years since the creation of the program, more than 500 undergraduate students have received graduate-level training in research methods and pressing political science topicsincluding both foreign and domestic policy topics. Each year, after the completion of the summer program, RBSI Scholars present their research posters at the annual meeting. Over 7o RBSI Scholars have earned PhDs in political science, with countless others earning law degrees, MAs, and PhDs in cognate fields. Looking toward the future, we send best wishes to the RBSI Scholars who are currently in graduate school and those 15 students who recently completed the 2016 program and are now known as the 3 oth anniversary class. Read their bios online at www.apsanet.org/rbsi2016.
At the heart of the RBSI program is teaching and training the future of the discipline. In a 1962 UN Radio interview, Ralph Bunche stated that he enjoyed teaching "more than anything I've ever done" and that it had been his "most rewarding" experience. Hewent on to remark that he "reaps the rewards" of following the careers, accomplishments, and successes of his former students. APSA thanks all of the faculty members, departments, and organizations, as well as the RBSI program faculty, teaching and graduate assistants, and program staff who have contributed toward the program's success. We invite you to learn more about the scholarly and professional contributions and the accomplishments of the RBSI Scholars by visiting www.apsanet.org/rbsizoforzo to read the "3o for 30 ," which spotlights 30 RBSI Alumni remarking on the zoth Anniversary and their experiences in the program. Following are a few highlights from the online spotlight feature.

\section{RBSI ALUMNI REFLECTIONS}

"The RBSI program enabled me to have a firmer grasp on the process it would take to attain the $\mathrm{PhD}$ and introduced me to leaders in the discipline with whom I would develop lifelong relationships."

-Nikol Alexander-Floyd, Associate Professor, Rutgers University RBSIClass of 1989

“Through the RBSI Program, I got a taste for conducting highquality, social science research and decided to focus on applying for a PhD program."

$$
\begin{array}{r}
\text {-Renata Barreto, University of California, Berkeley } \\
\text { RBSIClass of } 2012
\end{array}
$$

"Participating in the Ralph Bunche Summer Institute in 1988 changed my direction in life. I was able to become a teacher/scholar on race and politics and significantly impact the discipline on how we teach race and politics in American politics. It is a joy to be able to do what I do."

\section{-Sherri Wallace, Associate Professor, University of Louisville} RBSIClass of 1988

"Like most political science majors, I had high dreams of law school, and a plan of study to get me there. That all changed the summer (2007) I attended the Ralph Bunche Summer Institute (RBSI) at Duke; that experience is responsible for setting me on a professional-academic course that has been so rich in opportunity, friendship, and adventure."

\section{-Nyron N. Crawford, Assistant Professor, Temple University} RBSIClass of 2007

\footnotetext{
R E F E R E N C E S

Association News. 1996. PS: Political Science \& Politics 29 (217).

Jewel Prestage and Peter Zwick. 1986. Ford Funds Summer Institute for Black Students: A Report. PS: Political Science \& Politics 19 (898-902). doi:10.1017/ S1049096500018886. http://dx.doi.org/10.1017/S1049096500018886

United Nations Audiovisual Library. 1962. http://www.unmultimedia.org/avlibrary/ asset/C203/C2036/
} 